\title{
THE IMPORTANCE OF PARTICLE SIZE IN SAMPLES OF CERTAIN METALLURGICAL MATERIALS
}

\author{
By J. A. Scherrer and G. E. F. Lundell
}

\section{ABSTRACT}

The sampling of certain metallurgical materials gives rise to particles that differ in size and in composition. The extent of the differences is shown and the procedures that must be followed in selecting the sample for analysis are outlined.

\section{CONTENTS}

I. Introduction

II. Experimental 892

III. Conclusions. 895

\section{INTRODUCTION}

The segregation of metallic or nonmetallic elements in certain alloys, and its influence on methods of sampling for chemical analysis is well known. There is, however, another phase of the sampling of alloys that is often ignored; namely, that the large and the small sized particles of the sample may differ in composition.

If the particles differ in composition, it is evident that the sample for analysis must be taken with special care, and that analyses can not be expected to agree if some are made on coarse particles that have been obtained from the top of a container by pouring or by using pincers, and others are made on fine material left in the bottom of the container or scooped up from the edges of a poured-out sample by means of a spatula.

In preparing standard samples that are to be used in checking methods of chemical analysis, the chief requirements are that the samples be stable and of uniform composition. They need not represent the exact composition of the material from which they were obtained. A selected portion of the sample can, therefore, be taken for use as the standard, or the sample can even be prepared by a method which would be out of the question in selecting a sample for check analyses. Thus in the preparation of standard analyzed samples of cast iron it is customary to blow out all graphite dust and then to take a definite portion of the well-mixed sample, as, for example, the fraction that passes a No. 20 sieve and remains on a No. 35 sieve. Again, in the preparation of standard analyzed samples of bearing metals a uniform but not necessarily representative, sample is assured by atomizing the molten alloy and taking the fraction that passes a No. 100 sieve.

$$
11295^{\circ}-30-8
$$




\section{EXPERIMENTAL}

Most of the following tests on the composition of the different sized particles of certain materials were made in connection with the preparation of the bureau's standard analyzed samples. The samples of journal bearing, phosphor-lead bronze bearing metal, monotype metal, aluminum sand-casting alloy, duralumin, and samples 1 and 2 of zinc-base die-casting alloys were taken on a milling machine. The sample of cast iron and part of sample 3 of the zinc-base die-casting alloy were prepared on the lathe. The ferrotungsten sample was ground in a ball mill.

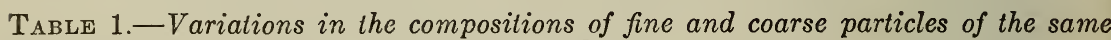
sample

JOURNAL BEARING

\begin{tabular}{|c|c|c|c|c|}
\hline \multirow[b]{2}{*}{ Constituent } & \multicolumn{4}{|c|}{ Fineness } \\
\hline & On No. 20 & $\begin{array}{l}\text { Through } \\
\text { No. 20; on } \\
\text { No. } 30\end{array}$ & $\begin{array}{l}\text { Through } \\
\text { No. } 30 ; \text { on } \\
\text { No. } 80\end{array}$ & $\begin{array}{l}\text { Through } \\
\text { No. } 80\end{array}$ \\
\hline 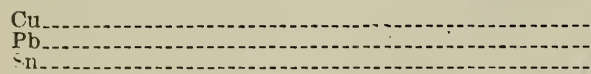 & $\begin{array}{r}70.0 \\
24.4 \\
4.9\end{array}$ & $\begin{array}{r}70.2 \\
24.1 \\
4.9\end{array}$ & $\begin{array}{r}67.6 \\
27.9 \\
4.7\end{array}$ & $\begin{array}{r}63.2 \\
31.2 \\
4.4\end{array}$ \\
\hline
\end{tabular}

PIOSPHOR-LEAD BRONZE BEARING METAL

\begin{tabular}{|c|c|c|c|c|c|}
\hline \multirow[b]{2}{*}{ Constituent } & \multicolumn{5}{|c|}{ Fineness } \\
\hline & On No. 20 & $\begin{array}{c}\text { Through } \\
\text { No. } 20 ; \text { on } \\
\text { No. } 40\end{array}$ & $\begin{array}{c}\text { Through } \\
\text { No. } 40 \text {; on } \\
\text { No. } 60\end{array}$ & $\begin{array}{l}\text { Through } \\
\text { No. } 60 \text {; on } \\
\text { No. } 100\end{array}$ & $\begin{array}{l}\text { Through } \\
\text { No. } 100\end{array}$ \\
\hline $\begin{array}{l}\mathrm{Cu} . \ldots \\
\mathrm{Pb} \\
\mathrm{Sn} \\
\mathrm{Zn} \\
\mathrm{P}\end{array}$ & $\begin{array}{c}81.2 \\
11.9 \\
5.2 \\
1.4 \\
.16\end{array}$ & $\begin{array}{r}79.8 \\
13.5 \\
5.1 \\
1.4 \\
.14\end{array}$ & $\begin{array}{c}77.1 \\
16.3 \\
5.0 \\
1.3 \\
.17\end{array}$ & $\begin{array}{r}71.5 \\
22.6 \\
4.5 \\
1.2 \\
.16\end{array}$ & $\begin{array}{r}66.1 \\
28.4 \\
4.2 \\
1.1 \\
.13\end{array}$ \\
\hline
\end{tabular}

MONOTYPE METAL

\begin{tabular}{|c|c|c|c|c|c|}
\hline \multirow[b]{2}{*}{ Constitnent } & \multicolumn{5}{|c|}{ Fineness } \\
\hline & On No. 20 & $\begin{array}{l}\text { Through } \\
\text { No. } 20 ; \text { on } \\
\text { No. } 40\end{array}$ & $\begin{array}{l}\text { Through } \\
\text { No. } 40 \text {; on } \\
\text { No. } 60\end{array}$ & $\begin{array}{l}\text { Through } \\
\text { No. } 60 ; \text { on } \\
\text { No. } 100\end{array}$ & $\begin{array}{l}\text { Through } \\
\text { No. } 100\end{array}$ \\
\hline $\begin{array}{l}\mathrm{Ph} \\
\mathrm{Sb} \\
\mathrm{S} n \\
\mathrm{Cu}\end{array}$ & $\begin{array}{c}71.5 \\
19.1 \\
9.3 \\
.03\end{array}$ & $\begin{array}{c}71.4 \\
19.2 \\
9.3 \\
.05\end{array}$ & $\begin{array}{c}71.6 \\
19.1 \\
9.2 \\
.07\end{array}$ & $\begin{array}{c}71.1 \\
19.3 \\
9.4 \\
.08\end{array}$ & $\begin{array}{l}67.1 \\
21.7 \\
10.9 \\
.08\end{array}$ \\
\hline
\end{tabular}

Each sample was put through appropriate sieves and the portions that are specified in the tables were analyzed for the constituents that are listed.

The data presented in Table 1 show that very great differences may exist between the compositions of fine and coarse particles of samples of alloys, such as journal bearings, bearing metals, and type metals. In fact, the differences may be so great that material meeting a speci- 
fication might easily be rejected on the basis of an analysis mado largely on the ine portions of the sample. For example, in the case of the journal bearings the analysis of tho coarse portion (on No. 20 sieve) passes the A. S. T. M. chemical composition requirement as to $\mathrm{Cu} 70 \pm 1.5, \mathrm{~Pb} 25 \pm 1.5$, and $\mathrm{Sn} 5 \pm 0.5$, while the portion that passes through the No. 80 sieve fails by a large margin.

The data shown in Table 2 indicate that diflerent sized particles of alloys, such as zinc-base die-casting alloys, aluminum sand-casting alloys, and duralumin do not show as great differences in composition as are illustrated in Table 1 . The distinctly higher iron content of the finer portions of the samples is, however, to be noted. In these samples all particles which were sufficiently magnetic to be picked up by a small permanent hand magnet were removed before making the analyses, but this procedure is not a sufficient guaranty that the higher iron content of the finer portions may not be due to iron abraded from the cutting tools during preparation of the samples. The more significant point for the purposes of the present consideration, is that the coarse and fine portions of the sample do not correspond in iron content. TABLE 2.-Variations in the compositions of fine and coarse particles of the same

ZINC-BASE DIE-CASTING ALLOYS

\begin{tabular}{|c|c|c|c|c|c|c|}
\hline \multirow{3}{*}{ Constituent } & \multicolumn{6}{|c|}{ Fineness } \\
\hline & \multicolumn{2}{|c|}{ Sample No. 1} & \multicolumn{2}{|c|}{ Sample No. 2} & \multicolumn{2}{|c|}{ Sample No. 3} \\
\hline & On No. 40 & $\begin{array}{c}\text { Through } \\
\text { No. } 40\end{array}$ & On No. 40 & $\begin{array}{c}\text { Through } \\
\text { No. } 40\end{array}$ & On No. 40 & $\begin{array}{c}\text { Through } \\
\text { No. } 40\end{array}$ \\
\hline 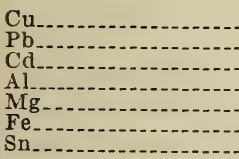 & $\begin{array}{c}2.82 \\
.03 \\
.007 \\
4.04 \\
.11 \\
.048\end{array}$ & $\begin{array}{l}2.82 \\
.03 \\
.004 \\
4.01 \\
.10 \\
.082\end{array}$ & $\begin{array}{c}2.86 \\
.32 \\
.29 \\
4.04 \\
.10 \\
.056\end{array}$ & $\begin{array}{r}2.84 \\
.32 \\
.29 \\
3.99 \\
.10 \\
.083\end{array}$ & $\begin{array}{c}2.95 \\
.60 \\
.10 \\
.57 \\
-.032 \\
5.95\end{array}$ & $\begin{array}{r}2.95 \\
.60 \\
.09 \\
.56 \\
.033 \\
6.01\end{array}$ \\
\hline
\end{tabular}

ALUMINUM SAND-CASTING ALLOY

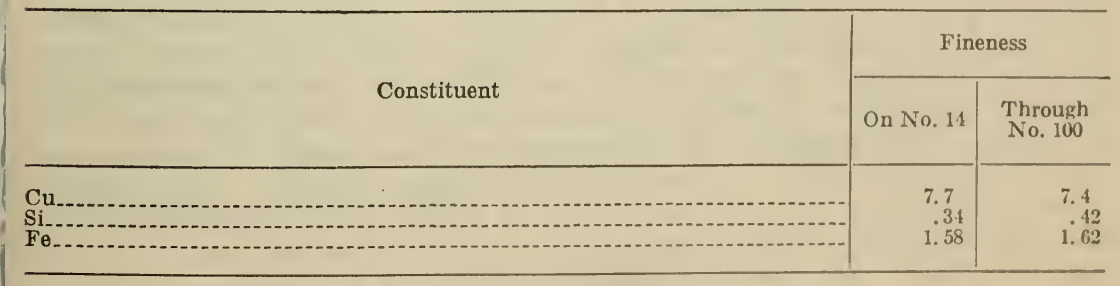

DURALUMIN

\begin{tabular}{|c|c|c|c|c|c|}
\hline \multirow[b]{2}{*}{ Constituent } & \multicolumn{2}{|c|}{ Fineness } & \multirow{2}{*}{ Constituent } & \multicolumn{2}{|c|}{ Fineness } \\
\hline & On No. 14 & $\begin{array}{l}\text { Through } \\
\text { No. } 100\end{array}$ & & On No. 14 & $\begin{array}{l}\text { Through } \\
\text { Nio. } 100\end{array}$ \\
\hline 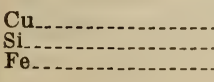 & $\begin{array}{l}4.1 \\
.45 \\
.43\end{array}$ & $\begin{array}{l}4.0 \\
.46 \\
.49\end{array}$ & $\begin{array}{l}M n_{1} \\
M \mathrm{gg}\end{array}$ & $\begin{array}{r}0.55 \\
.40\end{array}$ & $\begin{array}{r}0.55 \\
.41\end{array}$ \\
\hline
\end{tabular}


Differulties caused by segregation alone might be illustrated by the tin content of the zinc-base die-casting alloy No. 3. This alloy was cast as a slab (36 by 6 by 1 inch) and showed 0.3 per cent less tin ( 5.7 as against 6.0) in the middle than on the edge of the slab.

The variations in composition shown by coarse and fine particles of samples of cast iron and of ferrotungsten are shown in Table 3.

TABLY 3.-Tariations in the compositions of fine and coarse particles of the same sample

CAST IRON

(Froe graphite blown out before sieving)

\begin{tabular}{l|l|l|l}
\hline & \multicolumn{2}{|c}{ Fineness } \\
\hline Percentage of total carbon. . & $\begin{array}{c}\text { No. 30, on } \\
\text { No. } 40\end{array}$ & $\begin{array}{c}\text { Through } \\
\text { No. 20, on } \\
\text { No. 30 }\end{array}$ & $\begin{array}{c}\text { Through } \\
\text { No. 14, on } \\
\text { No. 20 }\end{array}$ \\
\hline
\end{tabular}

FERROTUNGSTEN

\begin{tabular}{|c|c|c|c|c|}
\hline \multirow[b]{2}{*}{ Sample } & \multicolumn{4}{|c|}{ Fineness } \\
\hline & On No. 100 & $\begin{array}{l}\text { Through } \\
\text { No. } 100 \text {, on } \\
\text { No. } 200\end{array}$ & $\begin{array}{l}\text { Through } \\
\text { No. } 200 \text {, on } \\
\text { No. } 325\end{array}$ & $\begin{array}{l}\text { Through } \\
\text { No. } 325\end{array}$ \\
\hline $\begin{array}{l}\mathrm{B}(100 \text { pounds, as received) } \\
\mathrm{B}^{\prime}(90 \text { pounds ground for } 90 \text { hours to pass No. } 325 \text { sieve) } \\
\mathrm{B}^{\prime \prime}{ }^{\prime \prime}(10 \text { pounds residue reground })\end{array}$ & Per cent W & $\begin{array}{r}\text { Per cent } W \\
82.8 \\
80.2 \\
92.0\end{array}$ & $\begin{array}{r}\text { Per cent W } \\
99.5 \\
90.5\end{array}$ & $\begin{array}{r}\text { Per cent } W \\
71.6 \\
70.4 \\
77.2 \\
82.8\end{array}$ \\
\hline
\end{tabular}

In the case of cast iron, sampling for analysis is complicated by the fact that while the fine particles of cast iron contain less carbon than the coarse particles, there is also present a goodly amount of graphite which has been torn from all of the particles.

The analyses of ferrotungsten illustrate difficulties that were cncountered in the preparation of a standard sample of ferrotungsten. Sample A was ground to pass a No. 100 sieve and when it was thoroughly mixed and sampled no difficulty was experienced in getting concordant determinations of tungsten that averaged 77.8 per cent. The question of homogeneity was raised, however, and the sample was sieved and the sieved fractions analyzed. The fraction passing through a No. 100 and held on a No. 200 sieve showed 82.8 per cent tungsten, while that passing a No. 325 sieve gave 71.6 per cent tungsten. Its use as a standard analyzed sample was given up because of the difference between the compositions of the particles. In view of the difficulties that were incurred in the preparation of sample A, sample B was sieved at the start and tungsten was determined in each fraction. The results were as follows: The portion held on a No. 100 sieve 77.6 per cent, the portion passing a No. 100, and held on a No. 200 sieve 80.2 per cent, the portion passing a No. 200 and held on a No. 325 sieve 79.5 per cent, and the portion passing a No. 325 sieve 70.4 per cent. As the fractions showed con- 
siderable differences in tungsten content and no fraction wa larer enough by itself, it was decided to crush and sieve the material until most of it passed a No. 325 sieve. Nincty out of the original one hundred pounds was so obtained and then thoroughly mixed and analyzed. The remaining 10 pounds were reground for a time and sieved. The fractions of this 10-pound lot were analyzed as a mutter of interest, but were not added to the standard.

\section{CONCLUSIONS}

If the sampling of a metallurgical material gives rise to particles that differ in size and in composition, the analysis must be made either on a single piece, on the whole sample, on a carefully sampled portion of a specially prepared sample, or on a portion which is made - up of proportionate parts of the varying sizes of the sample. As a general rule, a single piece can not be expected to represent the original material. Neither can a sample that is so small that all of it can be taken for the analysis. If the whole sample is to be used, it is better as a rule to get enough sample to make it representative and then to take an aliquot portion for analysis after dissolving the sample and diluting to a definite volume. If portions are to be taken from a large sample, the ideal sample is one in which there is no extreme variation between the sizes of the particles. If the particles are all comparatively small, a fairly representative portion for analysis can be obtained by spreading the sample out and taking small dab portions as in assaying. If it is not feasible to obtain small particles, a more representative analysis is obtained in most cases by taking the sample so as to get as little fine material as possible, sieving or shaking out the fines, and choosing particles of a size that is commensurate with the degree of segregation in the material and the weight of the portion to be taken for the analysis. Such a procedure fails if the composition of the fines differs very markedly from that of the coarse particles (as graphite in cast iron) and the formation of appreciable amounts of fines can not be avoided. In this case as well as for the most accurate sampling of material in which the composition varies with the size of particles, it is necessary to separate the sample into three or more parts by sieving without loss by dusting, then to weigh each part, and to take a proportionate part of each for the analytical sample. This has long been the practice in umpire determinations of carbon in cast iron, although in this case it is usually inferred that the only reason for the procedure is to take care of the accumulation of graphite in the fines.

Washington, July, 1930. 